\title{
Income Generation and Livelihood Security through Mushroom Production
}

\author{
Deepali Bajpai $^{*}$, Sanjeev Verma ${ }^{2}$, Yati Raj Khare ${ }^{3}$, \\ Aashutosh Sharma ${ }^{4}$ and A. K. Shrivastava ${ }^{5}$ \\ ${ }^{1}$ Directorate of Extension Services, JNKVV Jabalpur (MP), India \\ ${ }^{2}$ KrishiVigyan Kendra, Betul, India \\ ${ }^{3}$ KrishiVigyan Kendra, Narsinghpur, India \\ ${ }^{4}$ KrishiVigyan Kendra, Jabalpur, India \\ ${ }^{5}$ KrishiVigyan Kendra, Damoh, India \\ *Corresponding author
}

\section{A B S T R A C T}

\begin{tabular}{|l|}
\hline Ke y w or d s \\
$\begin{array}{l}\text { Mushroom, } \\
\text { Tribal, Oyster }\end{array}$ \\
\hline Article Info \\
$\begin{array}{l}\text { Accepted: } \\
\text { 20 December } 2020 \\
\text { Available Online: } \\
\text { 10 January } 2021\end{array}$ \\
\hline
\end{tabular}

The present study was conducted in tribal dominant block kesla district Hoshangabad (MP). Vocational training and demonstrations has been carried out in adopted villages of KVk.A net profit of Rs. 7080/- was achieved from 50 bags during the winter season as a source of extra income.

\section{Introduction}

District hoshangabad is located in central Narmada valley zone and blessed with full bowl of natural resources. District has seven Agricultural developmental kesla block is predominant have tribal population and have poor resources. Study of kesla block indicates that these tribal peoples are poor in resources and are migrating from one place to another place in the search of employment for survival and also for livelihood security. To arrest this migration income generation activities have been selected and disseminated in tribal areas, i.e. mushroom production technology has been popularized among tribal resource poor farm women. Mushroom production technology is low cost Technology. Mushroom being an indoor crop required very less space and no need of any costly infrastructure. It requires controlled conditions of temperature 14 to $19^{\circ} \mathrm{C}$ and humidity $85 \%$ at the time of fruiting. Oyster mushroom is grown on material which is prepared after mixing wheat or paddy straw and the spawn, on wheat or jowar grains. Mushroom entrepreneurship is more profitable than any other activities of income 
generation is stated in short time that is after 45 to 50 days after inoculation. To impact the vocational training and dissemination process for livelihood security of rural women was undertaken for the present study. For this trainings and demonstrations on mushroom production technology was conducted in PanduKhedi village by providing some critical input like spawn, fungicides, straw, and polythene bags.

Kesla block of hoshangabad selected for vocational training on mushroom production duing the year 2014-15. Training on cultivation and processing of mushroom has been given to resource poor farm women. Video film, literature also developed during training programs. Technical literature, group discussion exhibition, electronic media, seminar and meeting were incorporated for dissemination the mushroom cultivation to other women.

\section{Results and Discussion}

According to table, results revealed that growing of mushroom in poly bag, the cost of cultivation for 50 bags were 1500 rupees only whereas the gross return and net return of rupees 8580 and 7080 respectively. Arora R.K. (2015) and Nagraj et al., (2017) found that vocational training had increased the knowledge of farmers, farm women and youths regarding all the subcomponents of mushroom production.

Table.1 Cost of cultivation of mushroom

\begin{tabular}{|l|c|}
\hline Cost of cultivation (Rs) & 1500/-per family \\
\hline Days of first picking & 48 \\
\hline No. of pickings & 04 \\
\hline Market rate (Rs/kg) & 100 \\
\hline $\begin{array}{l}\text { Gross return (Rs./family 50 bags and one } \\
\text { crop of winter season }\end{array}$ & 8580 \\
\hline Net return (Rs./family) & 7080 \\
\hline Cost benifit & $1: 5.72$ \\
\hline
\end{tabular}

Photos of vocational training and mushroom unit develop at village pandukhedi
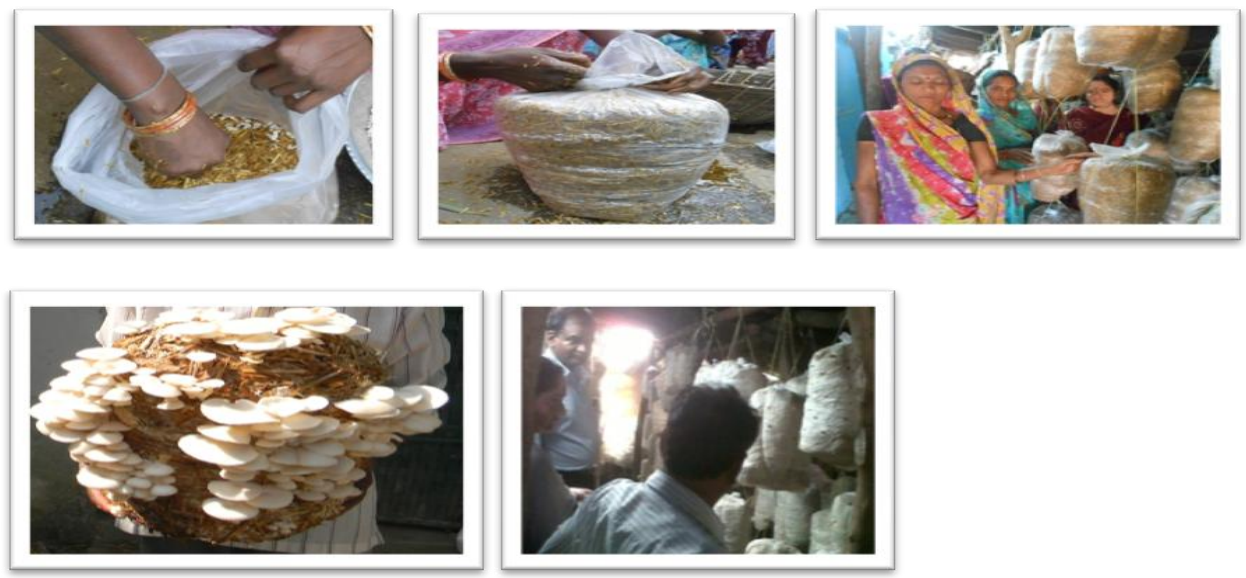
Agro-climate of the Hoshangabad district is suitable to higher production of oyster mushroom for 8 to 9 months that is June $2^{\text {nd }}$ week to March first week in the year. Tribal women's feel that business through mushroom production with low cost technology at home with minimum efforts. Oyster mushroom can be sold in dried form also. Production of oyster dry mushroom in the district was 1 , 48,00kg.Transportationto metro cities makes it possible to fetch @ Rupees 450 per kg of dried mushroom and give an economical gain and fetches a higher rate rupees 2,60,000.

A total of more than 200 women of the district is now producing mushroom in the sixteen villages of the district in the form of society by efforts of KVK scientist and cooperative society. These cooperative societies is working in the district in the form of the satpura mushroom, sahkaritamaryadit located in the village of the tribal dominant block kesla of the district Hoshangabad. Now more than two hundred Women are engaged in this entrepreneurship. More villages of the tribal area want to be included under the programme are as follows Sukhtawa, PanduKhedi, chandakiya, khohra, pipariya and Amrahi.

In conclusion by technological innovation significant increase was observed in resource poor farm families for adoption of mushroom production for income generation. Socioeconomic conditions of the resource poor farmers is uplifted along with nutritional security. Due to less involvement of infrastructure and cost, it is gaining popularity among landless farmers. Better transport facilities increases more cultivation of mushroom in tribal areas.

\section{References}

Arora, R. Kumar.2015. Impact of vocational training on mushroom production for self employment in district Ambala, Haryana . Int. J. Research advances in multidisciplinary research. 02(01): 171173

Nagaraj R., .Arunkumar P., Hanumanthaswamy, B.C. and RathodJyoti M. 2017.Mushroom Production for Self Employment - An Impact Study .Int.J.Curr.Microbiol.App.Sci (2017) 6(9): 2991-2997

Singh, M., Vijay B, Kamal, S. Wakchaure, G C. (2011) Mushrooms cultivations marketing and consumption. Director Directorate of Mushroom Research (ICAR) Chambaghat, Solan -173213 (HP)pp 1-274

\section{How to cite this article:}

Deepali Bajpai, Sanjeev Verma, Yati Raj Khare, Aashutosh Sharma and Shrivastava, A. K. 2021. Income Generation and Livelihood Security through Mushroom Production. Int.J.Curr.Microbiol.App.Sci. 10(01): 3317-3319. doi: https://doi.org/10.20546/ijcmas.2021.1001.388 